\title{
Os forais (charters) e o seu papel de limitar o poder governamental e garantir liberdades na tradição colonial norte-americana
}

\author{
The charters and its role to limit governing power and to \\ safeguard liberties in the American colonial tradition
}

\author{
GustaVo CASTAGnA MACHADO ${ }^{1}$
}

Doutorando em Direito (UFRGS); bolsista (CAPES)

\begin{abstract}
RESUMO: No presente artigo, busco investigar se os forais (charters) desempenhavam o papel de limitar o poder dos governos e de garantir liberdades na tradição colonial norte-americana. Na primeira parte deste artigo, analiso a organização jurídico-política das colônias, que, dentre outras coisas, normalmente possuíam três órgãos que correspondiam ao rei e às duas casas do Parlamento britânico, o que, em sua época, representava uma divisão de poderes. Na segunda parte deste artigo, adentro na investigação dos forais na tradição das colônias norte-americanas, analisando a sua relação com as cartas-patentes e chegando à conclusão de seu papel de limitar o poder do governo e garantir liberdades nas colônias norte-americanas.

Palavras-chave: Cartas-patente; Colônias norte-americanas; Divisão de poderes; Forais; Liberdade; Limitação de poderes.
\end{abstract}

ABSTRACT: In the present article I intend to investigate if the charters played a role to limit governing power and to safeguard liberties in the American colonies. In the first part of this article, I analyze the legal and political organization of the colonies, which, among another things, usually included three bodies that corresponded to the king and the two houses of the British Parliament, what, in its time, represented a division of powers. In the second part of this article, I delve in the investigation of the charters in the tradition of the American colonies, analyzing its relationship with the letters patent and coming to the conclusion of its role to limit governing power and safeguard liberties in the American colonies.

Keywords: Letters patent; American colonies; Division of powers; Charters; Liberty; Limited governing power.

\section{INTRODUÇÃO}

McLaughlin, em 1932, em seu The Foundations of American Constitutionalism identificava "certos princípios essenciais" de governo limitado no período pré-revolucionário estadunidense: pactos, representação, contrato social, revisão judicial (não necessariamente no sentido como compreendemos contemporaneamente a expressão inglesa judicial review, que pode significar controle de constitucionalidade os atos legislativos pelo judiciário ou controle dos atos administrativos pelo judiciário) e federalismo ${ }^{2}$.

Assim como a organização jurídico-política das colônias contribuiu para essa limitação, também contribuiu a tradição dos forais (charters). Assim, pretendo limitar-me aqui à análise dessas duas questões. Para Bilder ${ }^{3}$, que utilizo como referencial teórico, o estudo dos forais nas colônias norteamericanas é relevante na medida em que o giro de foral para Constituição é fundamental para o estudo da história constitucional estadunidense. A confiança inicial nesses forais é frequentemente citada como a criação de uma cultura que favoreceria as constituições escritas, ou devido à natureza escrita das liberdades do foral, ou devido ao hábito de se defender os forais contra a $\mathrm{Coroa}^{4}$. Conforme estudos recentes demonstram, no entanto, os boroughs ingleses tinham uma história longa e robusta de lidar com a defesa de forais e das liberdades por ele garantidas ${ }^{5}$. No entanto, o direito inglês não produziu uma cultura favorecendo constituições escritas. De fato, ocorreu sem dúvida o contrário. Em parte, uma Constituição escrita pode ser o produto da necessidade de declarar independência. Para Bilder, se os boroughs ingleses tivessem tentado declarar a independência, talvez eles também tivessem fundado a sua autoridade exclusivamente em um documento escrito. Os colonos norte-americanos, no entanto, estavam extremamente encantados com 
documentos escritos que servissem como fontes de limitações ao governo. ${ }^{6}$

Para Bilder, é certo que, antes de 1776, os colonos lidavam com forais; após 1776, eles escreveram constituições. No entanto, essa transformação verbal pode não significar a transformação imediata que nós supomos. ${ }^{7}$

No presente artigo, busco responder ao seguinte questionamento: o que eram os assim chamados forais e que papel desempenharam na ordem jurídico-política das colônias, especialmente no que tange à limitação dos poderes dos governantes?

Para tanto, divido o presente artigo em duas partes. A primeira é dedicada à investigação da organização jurídico-política das colônias e a segunda à investigação dos forais.

\section{ORGANIZAÇÃO JURÍDICO-POLÍTICA DAS COLÔNIAS}

Começo por algumas considerações gerais. Geralmente, as treze colônias são divididas, de acordo com a forma de governo, em três classes - a foral ${ }^{8}$ (charter), a real (royal) e a proprietária (proprietary), ${ }^{9}$ mas a crítica histórica feitas por autores como Osgood reduziu essas três formas a duas, a corporação (corporation) e a província (provincial), ${ }^{10}$ e penso que essa última classificação tem mais sentido. A corporação era idêntica à forma de foral e no início da Revolução havia apenas três, incluindo Massachusetts, ${ }^{11}$ as outras duas sendo Rhode Island e Connecticut. As formas provinciais incluíam as colônias proprietárias, Maryland, Pensilvânia e Delaware, e as colônias reais, Virginia, Carolina do Norte, Nova Hampshire, Vermont, Nova Jersey e Geórgia. ${ }^{12}$ As colônias proprietárias era muito similares em sua forma às colônias reais, tendo como grande diferença a substituição do rei pela figura do proprietário ${ }^{13}$.

As formas de governo colonial eram muito variáveis, e apenas duas colônias permaneceram sob a mesma forma da época de sua fundação até a Guerra Revolucionária. Essas duas foram as colônias forais de Rhode Island e Connecticut. No final do período colonial, predominava a forma real de governo, correspondendo a sete das treze colônias. O movimento contra as colônias forais e de propriedade que levou a essa condição foi iniciado no final do reinado de Carlos II, foi mantido por meio século e terminou em 1729 quando as Carolinas se tornaram províncias reais. Uma colônia, Geórgia, foi fundada após esse tempo e, após prosperar por dezenove anos como uma colônia proprietária, foi passada para a Coroa (1752) nos termos de seu foral. Massachusetts foi a primeira a se tornar uma vítima dessa nova política, perdendo o seu foral em 1684. Ao receber o seu novo foral, em 1691, Massachusetts se tornou uma província semirreal e é por alguns escritores colocada em uma classe isolada. Nova York, Nova Jersey e as Carolinas passaram para as mãos reais durante essa cruzada, e mesmo os governos da Pensilvânia e Maryland foram cada um, durante um curto período de tempo, tomados de seus respectivos proprietários ${ }^{14}$.

Ao deixar fora de consideração as duas colônias autodeterminadas, Rhode Island e Connecticut ${ }^{15}$, verificamos que a organização jurídico-política das colônias era surpreendentemente uniforme. Cada uma era composta por três órgãos ${ }^{16}$, (1) o governador, nomeado pela Coroa ou pelo proprietário ou proprietários, (2) o conselho (council), também nomeado pela Coroa, e (3) a assembleia ou a casa de representantes, eleita pelo povo. Segundo Elson, esses três órgãos, correspondentes ao rei e as duas casas do Parlamento, assemelhavam-se aos britânicos ${ }^{17}$.

O governador representava diretamente a Coroa ou o proprietário. Sua posição foi uma das mais difíceis de preencher. Representando um poder superior, pelo qual foi nomeado e do qual ele tinha instruções explícitas, no entanto ele devia um dever para com o povo sobre o qual ele foi colocado e os interesses dos dois eram tão conflitantes a ponto de manter o governador em uma constante agitação. Os poderes do governador eram amplos. Ele poderia convocar, prorrogar ou dissolver a legislatura, ou vetar qualquer de suas leis. Ele tinha o comando da milícia e nomeava muitos funcionários, como juízes, juízes de paz, xerifes e similares, e, especialmente no período inicial, ele tinha deveres industriais, comerciais e eclesiásticos, além dos políticos; mas em um aspecto ele sempre foi mantido em xeque: ele não tinha poder sobre o erário público. Muitos dos governantes eram homens honestos e fiéis aos seus deveres, mas outros, e talvez a maioria, eram homens devassos, os frutos do sistema de despojos daquela época, que vendiam os cargos à sua disposição, e que pouco se importavam com o bemestar dos colonos ${ }^{18}$.

O conselho consistia normalmente de doze homens, embora em Massachusetts houvesse 28 e inicialmente em Maryland apenas três. Eles tinham que ser moradores da colônia em que serviam, e eram geralmente homens de posição e riqueza. Nomeados pelo mesmo poder que nomeou o governador, eles geralmente alinhavam-se a ele em seus conflitos com a assembleia. As funções do conselho (council) eram tríplices, era um conselho (board) de conselheiros do governador, constituía a câmara alta do legislativo e com frequência formava a mais alta corte da colônia. 
Em Massachusetts, depois de 1691, o conselho passou a ser eleito por uma votação conjunta do legislativo, a chamada corte geral (General Court). Nas outras colônias provinciais era nomeado pela Coroa ou pelos proprietários $^{19}$.

A assembleia, ou a casa baixa da legislatura, representava o povo e era eleita por ele. Tinha o poder legislativo principal, mas seus atos poderiam ser vetados pelo governador, ou ser anulado pela coroa dentro de certo tempo após a sua aprovação. Mas a assembleia controlava a situação com o seu poder único de tributação. A esse direito a assembleia de cada colônia se apegava com ciúme tenaz. Por meio do exercício desse direito as colônias poderiam se dizer autodeterminadas, e as suas liberdades estavam seguras na medida em que elas pudessem manter esse direito exclusivo de tributar a si próprias. Por muitos anos o governo britânico lutou em vão com o problema de como obter uma receita americana para a Coroa. O governador, que representava a Coroa, e a assembleia, que representava o povo, estiveram em conflito frequente durante todo o período colonial e a assembléia geral normalmente vencia por meio de sua arma toda poderosa: a retenção de provisões. Em muitas ocasiões, a assembleia se recusaria a conceder ao governador o seu salário até que ele promulgasse algumas leis que a assembleia aprovou, embora muitas vezes o seu ato estivesse em direta violação de suas instruções. Também não era raro que a assembleia se tornasse arrogante e intrometida em assuntos puramente executivos, como assuntos militares, a nomeação de funcionários e similares, tudo isso por meio do seu poder sobre o erário público ${ }^{20}$.

A legislatura nas colônias era bicameral, exceto na Pensilvânia e Geórgia, nas quais ela era constituída por uma única casa. Esse sistema teve como o seu modelo bicameral o Parlamento, mas parecia brotar espontaneamente na América. Tudo começou em Massachusetts em 1644, quando a assembleia ou deputados pela primeira vez se assentou separadamente do conselho ou dos magistrados e os dois órgãos, doravante, se mantiveram separados. Outras colônias logo seguiram o exemplo, até que todas as legislaturas passaram a ser divididas, exceto na Pensilvânia, onde o conselho do rei não tinha funções legislativas após 1701, e na Geórgia. Em Connecticut e Rhode Island, e em Massachusetts antes de 1684 , o povo elegia o governador e, além da lei da navegação e de algumas outras leis restritivas, estavam na prática independentes da $\mathrm{Coroa}^{21}$.

O sistema de governo representativo, conforme Elson, era comum a todas as colônias, porém não foi introduzido na Geórgia antes de 1752. Tudo começou na Virginia com a primeira reunião dos burgueses ${ }^{22} \mathrm{em}$ 1619; ele foi introduzido em Massachusetts em 1634, e em Plymouth e em Maryland em 1639. O sistema de governo representativo era permitido, mas não exigido, pelos primeiros forais. Mas depois que se desenvolveu em várias colônias, ele foi reconhecido e ratificado pelos forais mais tarde, como naqueles de Connecticut e Rhode Island, e o segundo foral de Massachusetts, embora não tenha sido mencionado na concessão de Nova Iorque. A franquia chegou a ser restringida por algumas qualificações de propriedade em todas as colônias, na maioria por ato próprio, como na Virginia em 1670, ou por foral, como em Massachusetts, em $1691^{23}$. Em nenhuma colônia era encontrado o sufrágio universal ${ }^{24}$.

No sistema judicial, o juiz de paz (justice of peace) estava na parte inferior. Na maioria dos casos, ele era nomeado pelo governador, e ele julgava somente pequenos casos civis. Em seguida vieram os tribunais de condado (county courts), nos quais eram julgados processos cíveis que envolviam montantes de uma determinada quantia e processos criminais que não envolviam pena capital. O mais alto tribunal colonial era geralmente composto pelo governador e pelo conselho. Mas em algumas colônias o governador nomeou um grupo de juízes para essa função, enquanto ele e o conselho atuavam como um tribunal de apelações. Em certos casos, também, um novo apelo poderia ser feito para o conselho privado (privy council) da Inglaterra ${ }^{25}$.

Uma prática das colônias era manter um agente na Inglaterra para cuidar dos seus interesses. Essa prática teve origem no estado da Virgínia por volta de 1670 , e logo foi seguida por outras colônias. Às vezes, o mesmo agente representava duas ou mais colônias, como no caso de Franklin. As funções desses homens eram semelhantes às dos modernos representantes diplomáticos. Quase todas as questões coloniais eram encaminhadas ao board of trade (conselho do comércio) inglês, que se tornou uma instituição permanente após 1696, e o conselho as informava ao rei ou a um comitê do conselho privado (privy council). Era a esse conselho que os agentes coloniais apresentavam os interesses de suas respectivas colônias, e seus esforços fizeram muito para chegar a uma mais estreita camaradagem entre a metrópole e as colônias. Esse bom sentimento entre elas atingiu o ápice por volta do ano $1750^{26}$.

\section{O DESENVOLVIMENTO E AFIRMAÇÃO DOS FORAIS NAS COLÔNIAS E O SEU SIGNIFICADO JURÍDICO-POLÍTICO}

Um século antes da mudança de foral para Constituição, ocorreu uma mudança mais importante em 
solo estadunidense, quando os colonos desenvolveram a concepção de foral em oposição à de patente. Os colonos inicialmente não chamavam o que nós pensamos como um foral (charter) de foral, em vez disso eles chamavam de patente, abreviação de carta-patente (letters patent em inglês, ou litterce patentes em latim). O destacado estudioso da Connecticut Charter, Albert Bates, concluiu que as expressões "foral" e "patente" eram utilizadas como sinônimos ${ }^{27}$. Essa conclusão parece ser verdadeira em relação aos forais ingleses. As pessoas dos antigos boroughs (corporate towns) referiam-se às suas cartas-patentes constitutivas como cartas-patentes e forais. Entre as empresas de comércio, um uso semelhante da palavra "foral" parece ter sido comum. O foral publicado da Worshipful Company of Shipwrights (aproximadamente 1612) incluiu numerosas auto-referências a foral ${ }^{28}$. Historiadores fizeram suas próprias distinções. Os historiadores têm convencionalmente utilizado "patente" para se referir a um documento com menos autoridade (por exemplo, a Peirce Patent ou a Plymouth Patent) e reservado "foral" para o documento que afigura ser o ancestral genealógico de uma Constituição Estatal. Mas essa distinção é moderna ${ }^{29}$.

Qual foi a diferença histórica entre uma patente e um foral? Durante o período medieval, embora ambos tenham sido emitidos sob o Great Seal, os forais foram concedidos em perpetuidade, em latim, atestado por testemunhas, dirigido a um determinado grupo de funcionários e nobres, e registrado no charter rolls. "Carta-patente" se refere a um tipo mais geral de documento, assim chamado porque eles eram literalmente cartas-patentes, abertas, ao invés de cartas fechadas e eram dirigidas "a todos aqueles que a presente chegar". Após 1516, concessões a criar direitos em perpetuidade sob o selo - forais - foram criadas por cartas-patentes e registradas no patent rolls ${ }^{30}$. No entanto, "patente" manteve um significado distinto como uma concessão mais temporária de privilégios, um argumento reforçado pelo debate sobre os monopólios e o Statute of Monopolies (Estatuto dos Monopólios) (1623) ${ }^{31}$. Alguns analistas sugerem que a distinção "foral-patente" continuou com a cor do lacre utilizado: verde para os forais, amarelo (ou vermelho) para as patentes temporárias ${ }^{32,33}$.

Os colonos nas primeiras décadas do século XVII utilizavam a palavra "patente" acima de "foral". $\mathrm{Na}$ Virgínia, "patente" aparece onde seria de esperar a palavra "foral" 34 . As Orders and Constitutions (1619-1620) listavam livros a ser mantidos pelo secretário. O primeiro livro deveria incluir cópias das "Kings Letters Patents to the Companie" e o terceiro livro deveria incluir "Patents, Charters, and
Indentures" concedidas pela companhia ${ }^{35}$. Embora a própria companhia concedeu um "grande foral ou comissão de privilégios, ordens e leis" delegando a sua autoridade à corporação política local em 1618, ela continuamente se refere ao documento da Coroa como uma "patente" "36. A distinção é particularmente visível nos anos 1620, quando a Coroa tentou retirar de circulação (ou revogar) a Virginia Charter. A coroa descreveu o documento como um foral e os colonos responderam falando sobre uma carta-patente ${ }^{37}$. Além disso, a Companhia da Virgínia não fez qualquer esforço para publicar esses documentos ${ }^{38,39}$.

Os significados jurídicos e políticos de "foral" e de "patente" começam a se separar após a Revolução Inglesa. Por um lado, em Massachusetts, John Winthrop agarrou-se ao termo patente. Em seu "Discourse on Arbitrary Government" (Discurso sobre o governo arbitrário) de 1644, dedicou-se à autoridade jurídica transmitida pela "fundação" do governo sob uma "patente" ${ }^{40}$. Winthrop leu atentamente as cláusulas para estabelecer um governo "regulado" 41 . O Comitê dos Deputados em resposta argumentou que não encontrou qualquer "tal distinção na patente" 42 . No entanto, em outra ocasião desse mesmo ano, a palavra "foral" parecia estar crescendo em apelo. O parlamento deu a Rhode Island um "foral livre de constituição e governo civil" (os historiadores interessantemente a chamam de patente). Em 1649, o líder de Plymouth, Edward Winslow, chamou a Plymouth Patent de "seu foral"43. Em 1654, um "foral" de Barbados foi publicado. O recurso crescente à palavra "foral" para transmitir autoridade estava evidente no fato de que o documento não foi um foral, mas os Articles of Agreement (1651) entre os comissários da Coroa e o Lorde Willoughby de Parnham ${ }^{44}$. Inversamente, por volta de 1650 , um panfleto que ataca a concessão de Baltimore se recusou a chamá-lo de foral, referindo-se ao longo de ele a "a antijuridicidade de sua patente" ${ }^{\$ 5,46}$.

Ao escolher "foral" acima de "patente", os colonos de meados do século XVII absorveram em seus documentos a conotação de uma antiga concessão de liberdades, costumes e autodeterminação. Catherine Patterson observa que em boroughs ingleses o foral tinha "uma qualidade quase sagrada nas mentes da maioria dos cidadãos"47. Santidade era difícil de estabelecer em um documento recentemente concedido, ainda mais se frequentemente substituídos e eventualmente revogados. Na verdade, a mudança de ortografia de "Magna Carta", reforçou essa associação entre um foral e antigas liberdades e autoridades ${ }^{48}$. Em meados do século XVII, a maioria dos tratados políticos preferiam a ortografia "Magna Charta" com "ch" para aproximar uma semelhança visual com 
"charter", "foral". O English Liberties: or, The FreeBorn Subjects Inheritance de Henry Care de 1682 é a mais notável dessas obras ${ }^{49}$. Em 1689, Gershom Bulkeley referiu-se a "antigos privilégios forais" da decididamente não antiga Connecticut Charter ${ }^{50,51}$.

Nos anos de 1680, ironicamente, os forais se tornaram vulneráveis a mandado de quo warranto, um procedimento jurídico para revogar um foral. A coroa, pela "primeira vez em séculos, batalhou por quo warrantos até a decisão final" 52 . Mais chocante para os colonos foi a revogação do conhecido antigo foral de Londres em 1681-1683. Na Inglaterra, após 1680, a controvérsia produziu múltiplas impressões do foral de Londres e livros sobre os procedimentos de quo warranto, muitos dos quais atravessaram o Atlântico para observadores interessados. As folha de rosto dessas publicações de foral enfatizaram a importância de sua colocação em impressão "literal" com comentários para o público ${ }^{53,54}$.

Apesar de que essas publicações não impediram a perda do foral de Londres, os colonos perceberam a publicação como um método de declaração da autoridade jurídica e local ${ }^{55}$.

A autoridade colonial foi literalmente escrita grande nesses novos forais impressos. O Massachusetts Charter de 1691 apareceu impresso em 1692. Na folha de rosto, Charter e New-England apareciam em uma fonte bem grande, superando o reconhecimento muito menor "concedido por suas Majestades o Rei Guilherme e Rainha Maria" ${ }^{56}$. Por volta do século XVIII, as coleções de estatutos coloniais que começaram com o foral visivelmente insistiram que a autoridade jurídica surgiu a partir dos forais ${ }^{57}$. Imprimir os forais distanciou-os da prerrogativa da Coroa e converteu-os em questões de direito. Assim, em 1721, Jeremiah Dummer escreveu Defense of the New-England Charters para explicar o "direito que os governos de foral têm àqueles privilégios" ${ }^{58}$. Essa percepção de que os forais representavam a autoridade colonial independente em vez de concessões reais aumentou ainda mais por volta de 1760. Em 1764, John Dickinson, assim escreveu sobre a Constituição colonial da Pensilvânia: "Deixe qualquer pessoa imparcial refletir quão contraditórios alguns desses privilégios são para os mais antigos princípios da constituição inglesa, e quão diretamente opostos outros de eles são para as estabelecidas prerrogativas da coroa" 59 . Segundo Bilder, os forais impressos tornaram-se propriedade dos colonos, e não da $\mathrm{Coroa}^{60}$.

Forais, assim, encarnaram Constituições coloniais. A Laws of Maryland de 1765 teve como objetivo incluir as questões "relativas à Constituição" da província, e central da qual era o foral, ressaltado na folha de rosto com letras grandes ${ }^{61}$. Em 1774 e 1775, o Congresso Continental enquadrou as suas respostas às ações do Reino Unido em Massachusetts como violações e subversões do foral ${ }^{62}$. A Constituição da Carolina do Sul de março de 1776 condenou alterações materiais na "constituição foralizada do governo". Em 1776, Thomas Paine, prescrevia que "os artigos ou forais do governo" devem preceder a escolha de homens para executar o governo ${ }^{63}$. Ele propôs um "Foral Continental, ou Foral das Colônias Unidas, (respondendo ao que é chamado de Carta Magna da Inglaterra)" para a nova nação ${ }^{64}$. A Declaração de Independência ecoou esse reposicionamento do foral como um direito colonial. Ela condenou o rei por "tirar nossos forais" $" 65$.

Os novos estadunidenses passariam a escrever documentos que eles viriam a chamar de Constituições, porque eles literalmente constituíam uma nova ordem jurídico-política. Aos poucos, "Constituição" tornou-se o nome de tais documentos ${ }^{66}$. De fato, James Madison inicialmente descreveu os Articles of Confederation como uma "Constituição federal" em seu Notes of the Constitutional Convention de $1787^{67}$. Esses documentos escritos estavam baseados na concepção colonial de um foral, no qual a autoridade pública, não a autoridade da Coroa, era declarada e definida. Assim, Rhode Island e Connecticut inicialmente estavam completamente confortáveis com a manutenção de forais coloniais uma vez que as referências à Coroa tinham sido eliminadas ${ }^{68}$. Já em 1819, James Madison escreveu: "Isso não podia deixar de acontecer, e estava previsto no nascimento da Constituição, que as dificuldades e diferenças de opinião podem ocasionalmente surgir ao interpretar termos e frases necessariamente utilizados em tal foral" ${ }^{69}$. A Constituição foi um tipo de foral - um tipo especial, que os colonos tinham tentado reivindicar por anos ${ }^{70}$.

\section{CONSIDERAÇÕES FINAIS}

$\mathrm{Na}$ primeira parte deste artigo, vimos a organização jurídico-política das colônias, que era surpreendentemente uniforme e formada por três órgãos que correspondiam ao rei e as duas casas do Parlamento, assemelhando-se aos britânicos em uma estrutura que, em sua época, representava uma divisão de poderes, não necessariamente correspondente ao que contemporaneamente entendemos como divisão de poderes. Essa primeira é muito relevante para a segunda, na medida em que podemos avaliar em que contexto jurídico-político a doutrina dos forais se desenvolveu.

Na segunda parte deste artigo, investiguei os forais na tradição das colônias norte-americanas, sua relação 
com as cartas-patentes e a sua consolidação como limitadores de poder e garantidores de liberdades.

$\mathrm{O}$ estudo dos forais nas colônias indica, em tema a ser aprofundado em outra pesquisa, que a adoção do termo "Constituição" pode não ter sido uma ruptura com o passado colonial, mas um aperfeiçoamento ou aprofundamento de uma prática ${ }^{71}$. A substituição técnica da Coroa pelas pessoas como a suprema fonte de autoridade governamental foi significativa, mas não significa que o imaginário jurídico e suas práticas desapareceram ou foram modificadas drasticamente. Os modos de prática jurídica no mundo foralizado continuaram a ser relevantes para a prática jurídica em um mundo constitucional. Transferir essa transformação para o final do século XVII, na crença crescente em um foral impresso à disposição do público como fonte e limite da autoridade governamental parece sugerir uma tradição constitucional que atravessa o período de fundação, em vez de iniciar nele ${ }^{72}$.

\section{REFERENCIAS}

ADAMS, Willi Paul. The First American Constitutions: Republican Ideology and the Making of the State Constitutions in the Revolutionary Era. Translated by Rita and Robert Kimber. Lanham, Md.: Rowman \& Littlefield, 2001 (1973).

BALTIMORE, Cecil Calvert. The Lord Baltemores Case Concerning the Province of Maryland, adjoyning to Virginia in America. London: [s.n.], printed in the yeare, 1653.

BARBADOS. [Acts and statutes] of the island of Barbados made and enacted since the reducement of the same, unto the authority of the Common-wealth of England and set forth the seventh day of September, in the year of our Lord God 1652, by the Honourable governour of the said island, the worshipfull the council, and gentlemen of the assembly; together with charter of the said island, or articles made on the surrender, and rendition of the same; published for the publick good. London: Printed by Will Bentley, 1654.

BATES, Albert Carlos. The Charter of Connecticut. Hartford: Connecticut Historical Society, 1932.

BILDER, Mary Sarah. Colonial Constitutionalism and Constitutional Law. In: BROPHY, Alfred L.; HAMILTON, Daniel W. (Ed.). Transformations in American Legal History: Essays in Honor of Morton J. Horwitz. Cambridge: Harvard Law School, 2009. p. 28-57.

BOND, Shelagh; EVANS, Norman. The Process of Granting Charters to English Boroughs, 1547-1649. English Historical Review, Oxford, v. 91, p. 102-120, 1976.

BRADFORD, William. Of Plymouth Plantation, 1620-1647: The Complete Text. New York: Knopf, 1952.

BROPHY, Alfred L.; HAMILTON, Daniel W. (Ed.). Transformations in American Legal History: Essays in Honor of Morton J. Horwitz. Cambridge: Harvard Law School, 2009. 407 p.

BULKELEY, Gershom. The People's Right to Election: or, Alteration of Goverment in Connecticut. Philadelphia: Printed by Assignes of William Bradford, 1689.

CONNECTICUT. \& England and Wales. Sovereign (1660-1685: Charles II). The charter granted by His Majesty King Charles II to the governour \& company of the English colony of Connecticut in New-England in America. New-London, Conn.: Printed and sold by Timothy Green: 1718 .
CORPORATION OF LONDON. The abridgement of the charter of the city of London being every free-man's privilege / exactly translated from the original record and rendered faithfully into English according to the said record itself from the time of William the Conquerour ... to the time of our now Sovereign Lord King Charles the Second ... [s.n.]. London, 1680.

CORPORATION OF LONDON. The royal charter of confirmation granted by King Charles II to the city of London. Wherein are recited verbatim, all the charters to the said city, granted by His Majesties royal predecessors, kings and queens of England. / Taken out of the records, and exactly translated into English by S.G. gent.; Together with an index or alphabetical table, and a table explaining all the obsolete and difficult words in the said charter. London: Printed for Samuel Lee and Benjamin Alsop, 1680.

DUMMER, Jeremiah. A Defence of the New-England Charters. Boston: Reprinted by S. Kneeland for S. Gerrish and D. Henchman, 1721.

ELSON, Henry William. History of the United States of America. New York: MacMillan, 1904.

ERDMAN JR., Charles R. The New Jersey Constitution of 1776. Princeton, N.J.: Princeton University Press, 1929.

FARRAND, Max (Ed.). The Records of the Federal Convention. New Haven: Yale University Press, 1966. 3 v.

FORD, Paul Leicester (Editor). The Writings of John Dickinson. Philadelphia: Historical Society of Pennsylvania, 1895.

FORD, Worthington C.; HUNT, Gaillard; FITZPATRICK, John Clement; HILL, Roscoe R.; HARRIS, Kenneth E.; TILLEY, Steven D. (Ed.). Journals of the Continental Congress, 17741789. Washington, D.C.: Government Printing Office, 1904-1937. $34 \mathrm{v}$.

GREAT BRITAIN. Calendar of the Charter Rolls. London: His Majesty's Stationery Office, 1906. 2 vols.

GROSSBERG, Michael; TOMLINS, Christopher (Ed.). The Cambridge History of Law in America. New York: Cambridge University Press, 2011. v. 1. 758 p.

HALliDAY, Paul D. Dismembering the Body Politic: Partisan Politics in England's Towns, 1650-1730. Cambridge: Cambridge University Press, 1998.

HART, James S.; ROSS, Richard J. The Ancient Constitution in the Old World and the New. In: BREMER, Francis J.; BOTELHO, Lynn A. (Ed.). The World of John Winthrop: Essays on England and New England 1588-1649. Boston: Massachusetts Historical Society, 2005.

HARVEY, Ray Forrest. Jean Jacques Burlamaqui: A Liberal Tradition in American Constitutionalism. Chapel Hill: University of North Carolina Press, 1937.

HOWARD, A. E. Dick. The Road from Runnymede: Magna Carta and Constitutionalism in America. Charlottesville: University of Virginia Press, 1968.

HUTTON, Patrick H. The Print Revolution of the Eighteenth Century and the Drafting of Written Constitutions. Vermont History, Barre, v. 56, Issue 3, p. 154-165, 1988

KINGSBURY, Susan Myra (Ed.). The Records of the Virginia Company of London. Washington, D.C.: U.S. Government Printing Office, 1906-1935. $4 \mathrm{v}$.

MASSACHUSETTS. The charter granted by Their Majesties King William and Queen Mary, to the inhabitants of the province of the Massachusetts-Bay in New-England. Boston: Printed by B. Green for Benjamin Eliot, 1714-1723.

MASSACHUSETTS HISTORICAL SOCIETY. Winthrop Papers. Boston: John Wilson and Son, 1929-1947. $5 \mathrm{v}$.

MCLAUGHLIN, Andrew C. The Foundations of American Constitutionalism. Union, N.J.: Lawbook Exchange, 2002. 
MOREY, W. C. The First State Constitutions. The Annals of the American Academy of Political and Social Science, Newbury Park, v. IV, n. 2, p. 201-232, Sept. 1893.

OSGOOD, Herbert Levi. The American Colonies in the Seventeenth Century. New York: Columbia University Press, 1904-07. 3 v.

PAINE, Thomas. Common Sense. London: Penguin, 2005.

PATTERSON, Catherine F. Urban Patronage in Early Modern England: Corporate Boroughs, the Landed Elite, and the Crown, 1580-1640. Stanford, Calif.: Stanford University Press, 1999.

PAULETTE, Justin. Colonial Charters and Grants. In: MILLER, Wilbur R. (Ed.). The Social History of Crime and Punishment in America. An Encyclopedia. Thousand Oaks: SAGE, 2012. p. $287-290$.

PENN, William. The Excellent Priviledge of Liberty and Property Being the Birth-Right of the Free-born Subjects of England. Clark, N.J.: The Lawbook Exchange, 1897 (1687).

PENNSYLVANIA. A Collection of charters and other publick acts relating to the province of Pennsylvania, viz. I. The royal charter to William Penn, Esq. II. The first frame of government, granted in England, in 1682. III. Laws agreed upon in England. IV. Certain conditions or concessions. V. The act of settlement, made at Chester, 1682. VI. The second frame of government, granted 1682. VII. The charter of the city of Philadelphia, granted October 25. 1701. VIII. The new charter of privileges to the province, granted October 28, 1701 (1740); A Defence of the legislative constitution of the province of Pennsylvania, as it now stands confirmed and established, by law and charter. With some observations on the proceedings published by sixteen members of Assembly, in a paper, entitled, The votes and proceedings of the House of Representatives: recommended to the consideration of all the free men of the province. Philadelphia: Printed and sold by B. Franklin, 1740 (1728).

RHODE-ISLAND AND PROVIDENCE-PLANTATIONS. The charter granted by His Majesty King Charles the Second, to the colony of Rhode-Island, and Providence-Plantations in America. Rhode-Island: Printed by James Franklin, 1730 (1719).

ROSS, Richard J. Legal Communications and Imperial Governance: British North America and Spanish America Compared. In: GROSSBERG, Michael; TOMLINS, Christopher (Ed.). The Cambridge History of Law in America. New York: Cambridge University Press, 2011. v. 1. p. 104-143.

SCHWOERER, Lois G. The Ingenious Mr. Henry Care: Restoration Publicist. Baltimore, Md.: Johns Hopkins University Press, 2001.

STRACHEY, William. For the Colony in Virginea Britannia. Lavves diuine, morall and martiall, \& $c$. London: Printed for W. Burre, 1612.

THORPE, Francis Newton. A Constitutional History of the American People, 1776-1850. New York: Harper \& Bros., 1898. $2 \mathrm{v}$.

UNITED STATES OF AMERICA. Documentary history of the Constitution of the United States of America, 1786-1870: derived from records, manuscripts, and rolls deposited in the Bureau of Rolls and Library of the Department of State. Washington: Department of State, 1894-1905. 5 vols.

WARNER, Michael. Letters of the Republic: Publication and the Public Sphere in Eighteenth-Century America. Cambridge, Mass.: Harvard University Press, 1990.

WILLIAM III, King of England; MARY II, Queen of England. The charter granted by Their Majesties King William and Queen Mary, to the inhabitants of the province of the Massachusetts-Bay, in New-England. Boston: Samuel Kneeland and Timothy Green, 1742 (1692).

WINSLOW, Edward. The Danger of Tolerating Levellers in a Civil State. London: Printed by Rich, 1649.

WRIGHT JR., Benjamin F. The Early History of Written Constitutions in America. In: WITTKE, Carl Frederick (Ed.). Essays in History and Political Theory in Honor of Charles Howard McIlwain. Cambridge, Mass.: Harvard University Press, 1936.

\section{NOTAS}

1 Doutorando em Direito pela Universidade Federal do Rio Grande do Sul (UFRGS), com bolsa da CAPES. Mestre em Direito (UFRGS), com bolsa do CNPQ. MBA em Direito Tributário pela Fundação Getúlio Vargas (FGV). Bacharel em Ciências Jurídicas e Sociais pela Pontifícia Universidade Católica do Rio Grande do Sul (PUCRS).

2 Andrew C. McLaughlin, The Foundations of American Constitutionalism (1932; Union, N.J.: Lawbook Exchange, 2002), 135; ver também Ray Forrest Harvey, Jean Jacques Burlamaqui: A Liberal Tradition in American Constitutionalism (Chapel Hill: University of North Carolina Press, 1937) (Mary Sarah Bilder, Colonial Constitutionalism and Constitutional Law, In: Alfred L. Brophy and Daniel W. Hamilton (editors), Transformations in American Legal History: Essays in Honor of Morton J. Horwitz, Cambridge: Harvard Law School, 2009, p. 47).

3 BILDER, Mary Sarah. Colonial Constitutionalism and Constitutional Law. In: BROPHY, Alfred L.; HAMILTON, Daniel W. (Editors). Transformations in American Legal History: Essays in Honor of Morton J. Horwitz. Cambridge: Harvard Law School, 2009, p. 28-57.

4 Ver, por exemplo, McLaughlin, The Foundations of American Constitutionalism. Union, N.J.: Lawbook Exchange, 2002, p. 47 (que contabiliza, entre outros fatores, o provável efeito psicológico de viver durante anos sob um governo cuja autoridade estava limitada, em teoria, dentro das limitações da escrita); Benjamin F. Wright Jr., The Early History of Written Constitutions in America, in: WITTKE, Carl Frederick (editor), Essays in History and Political Theory in Honor of Charles Howard McIlwain. Cambridge, Mass.: Harvard University Press, 1936, pp. 344-71 (Mary Sarah Bilder, Colonial Constitutionalism and Constitutional Law, In: Alfred L. Brophy and Daniel W. Hamilton (editors), Transformations in American Legal History: Essays in Honor of Morton J. Horwitz, Cambridge: Harvard Law School, 2009, p. 49).

5 Ver os trabalhos de Catherine F. Patterson (Urban Patronage in Early Modern England: Corporate Boroughs, the Landed Elite, and the Crown, 1580-1640, Stanford, Calif.: Stanford University Press, 1999) e Paul Halliday (Dismembering the Body Politic: Partisan Politics in England's Towns, 1650-1730. Cambridge: Cambridge University Press, 1998).

6 BILDER, Mary Sarah. Colonial Constitutionalism and Constitutional Law. In: BROPHY, Alfred L.; HAMILTON, Daniel W. (Editors). Transformations in American Legal History: Essays in Honor of Morton J. Horwitz. Cambridge: Harvard Law School, 2009, p. 31.

7 BILDER, Mary Sarah. Colonial Constitutionalism and Constitutional Law. In: BROPHY, Alfred L.; HAMILTON, Daniel W. (Editors). Transformations in American Legal History: Essays in Honor of Morton J. Horwitz. Cambridge: Harvard Law School, 2009, p. 31.

8 Existia diferença entre uma colônia ter um foral e ser, digamos, "foralizada". Espero que isso possa ser percebido com mais clareza ao fim da leitura do presente artigo. Quando é falado aqui de uma classe de governo "foral", é falado no sentido de uma forma de governo "foralizado".

9 ROSS, Richard J. Legal Communications and Imperial Governance: British North America and Spanish America Compared. In: GROSSBERG, Michael; TOMLINS, Christopher (Editors). The Cambridge History of Law in America. Volume 1. New York: Cambridge University Press, 2011, p. 129.

${ }^{10}$ Em seu clássico The American Colonies in the Seventeenth Century (Herbert Levi Osgood, The American Colonies in the Seventeenth Century, Volume 1. New York: Columbia University Press, 1904, p. xxviii), Osgood mostra que o "foral" não indica uma forma de governo, é simplesmente uma concessão do poder de certos direitos que podem ou não pertencer ao estabelecimento da colônia. Ao conceder um foral colonial o rei criou uma corporação e deu-lhe o poder para fundar e reger uma colônia. O governo foi, portanto, um governo pela corporação de 
acordo com certas orientações dadas no foral (Henry William Elson, History of the United States of America, New York, The MacMillan Company, 1904, p. 211)

${ }^{11}$ Mais estritamente, Massachusetts foi uma corporação apenas antes de 1684, após 1691 era uma colônia real, com um foral.

${ }^{12}$ ELSON, Henry William. History of the United States of America. New York: The MacMillan Company, 1904, p. 210-211.

${ }^{13}$ ELSON, Henry William. History of the United States of America. New York: The MacMillan Company, 1904, p. 211.

${ }^{14}$ PAULETTE, Justin. Colonial Charters and Grants. In: MILLER, Wilbur R. (Editor). The Social History of Crime and Punishment in America. An Encyclopedia. Thousand Oaks: SAGE, 2012, p. 289.

${ }^{15}$ Para o governo dessas, ver Henry William Elson, History of the United States of America, New York, The MacMillan Company, 1904, p. 107 e 113.

${ }^{16}$ Exceto a Pensilvânia e a Geórgia. Ver W. C. Morey, The First State Constitutions. The Annals of the American Academy of Political and Social Science, Newbury Park, Volume IV, No. 2, September 1893, p. 215.

17 ELSON, Henry William. History of the United States of America. New York: The MacMillan Company, 1904, p. 211.

${ }^{18}$ ELSON, Henry William. History of the United States of America. New York: The MacMillan Company, 1904, p. 211-212.

${ }^{19}$ ELSON, Henry William. History of the United States of America. New York: The MacMillan Company, 1904, p. 212.

${ }^{20}$ ELSON, Henry William. History of the United States of America. New York: The MacMillan Company, 1904, p. 212-213.

${ }^{21}$ ELSON, Henry William. History of the United States of America. New York: The MacMillan Company, 1904, p. 213.

22 Palavra que no contexto anglo-saxão tinha originalmente o sentido de se referir aos homens livres dos boroughs ingleses.

23 "Votava a propriedade, não os homens", diz Thorpe (Francis Newton Thorpe, A Constitutional History of the American People, 1776-1850, Volume 1, New York: Harper \& Bros., 1898, p. 192). O teste religioso era também aplicado de alguma forma em todas as colônias.

${ }^{24}$ ELSON, Henry William. History of the United States of America. New York: The MacMillan Company, 1904, p. 213.

${ }^{25}$ ELSON, Henry William. History of the United States of America. New York: The MacMillan Company, 1904, p. 213-214.

${ }^{26}$ ELSON, Henry William. History of the United States of America. New York: The MacMillan Company, 1904, p. 214.

27 BATES, Albert Carlos. The Charter of Connecticut. Hartford: Connecticut Historical Society, 1932, p. 5.

${ }^{28}$ Worshipful Company of Shipwrights (aproximadamente 1612) (incluindo foral, atos e decretos, e confirmação de eles por Ellesmere, Fleming e Coke).

29 BILDER, Mary Sarah. Colonial Constitutionalism and Constitutional Law. In: BROPHY, Alfred L.; HAMILTON, Daniel W. (Editors) Transformations in American Legal History: Essays in Honor of Morton J. Horwitz. Cambridge: Harvard Law School, 2009, p. 32.

30 Shelagh Bond and Norman Evans, The Process of Granting Charters to English Boroughs, 1547-1649. English Historical Review, Oxford, Volume 91, pp. 102-20, 1976. Sobre os primeiros forais, ver Great Britain, Calendar of the Charter Rolls, London: His Majesty's Stationery Office, 1906. 2 vols. (Mary Sarah Bilder, Colonial Constitutionalism and Constitutional Law, In: Alfred L. Brophy and Daniel W. Hamilton (editors), Transformations in American Legal History: Essays in Honor of Morton J. Horwitz, Cambridge: Harvard Law School, 2009, p. 50).

${ }^{31}$ Ver An Act Concerning Monopolies and Dispensations with Penal Laws, and the Forfeitures, 21 Jac. 1, c. 3, sec. 6 (1622).

32 BATES, Albert Carlos. The Charter of Connecticut. Hartford: Connecticut Historical Society, 1932. Sobre o Grande Selo, consultar H. C. Maxwell-Lyte, Historical Notes on the Use of the Great Seal of England, London: H. M. Stationery Office, 1926 (Mary Sarah Bilder, Colonial Constitutionalism and Constitutional Law, In: Alfred L. Brophy and Daniel W. Hamilton (editors), Transformations in American Legal History: Essays in Honor of Morton J. Horwitz, Cambridge: Harvard Law School, 2009, p. 50).

33 BILDER, Mary Sarah. Colonial Constitutionalism and Constitutional Law. In: BROPHY, Alfred L.; HAMILTON, Daniel W. (Editors). Transformations in American Legal History: Essays in Honor of Morton J. Horwitz. Cambridge: Harvard Law School, 2009, p. 32.

34 William Bradford referiu-se aos documentos de Virgínia e Plymouth como patentes. Ver William Bradford, Of Plymouth Plantation, 16201647: The Complete Text, New York: Knopf, 1952, p. 38; ver também p. 215 (a respeito do procedimento do Sr. Allerton sobre a ampliação e confirmação de sua patente), Sherley and Haterford to Bradford, Mar.
$16,1629 / 30$ (descrevendo que "o nosso interesse principal, a patente, foi concedida" e acrescentando que viraram uma corporação de modo a "permitir você a criar e executar legislações de forma tão geral e ampla quanto a Massachusetts Plantation pode". No que nós pensamos como a Peirce Patent, Thomas Weston chamou de um "foral, o melhor que poderíamos, o qual é melhor do que o seu anterior, e com menos limitações", Thomas Weston to Bradford, July 6, 1621, Of Plymouth Plantation, p. 93. Ver também Copy of Order of the Privy Council (Jan. $19,1632 / 33]$ ), p. 421-22 (discutindo problemas com as "patentes" da Nova Inglaterra) (Mary Sarah Bilder, Colonial Constitutionalism and Constitutional Law, In: Alfred L. Brophy and Daniel W. Hamilton (editors), Transformations in American Legal History: Essays in Honor of Morton J. Horwitz, Cambridge: Harvard Law School, 2009, p. 50).

35 Orders and Constitutions ... 1619 and 1620, The Records of the Virginia Company of London, Susan Myra Kingsbury (editor), Washington, D.C.: U.S. Government Printing Office, 1906-1935, v. 3, p. 352-353; ver também v. 1, p. 257 ("os habitantes tiveram uma grande alegria com os Forais de Garantias e Liberdades recentemente enviados pelo Sr Geo: Yeardley", Quarter Court, Nov. 3, 1619) (Mary Sarah Bilder, Colonial Constitutionalism and Constitutional Law, In: Alfred L. Brophy and Daniel W. Hamilton (editors), Transformations in American Legal History: Essays in Honor of Morton J. Horwitz, Cambridge: Harvard Law School, 2009, pp. 50-51).

${ }^{36}$ PORY, John. A Reporte of the Manner of Proceeding in the General Assembly Convented at James City 1619. In: KINGSBURY, Susan Myra (editor). The Records of the Virginia Company of London. Washington, D.C.: U.S. Government Printing Office, 1906-1935, v. 3, p. 158; Treasurer and Company, An Ordinance and Constitution for Council and Assembly in Virginia, July 24, 1621, v. 3, p. 484 (Mary Sarah Bilder, Colonial Constitutionalism and Constitutional Law, In: Alfred L. Brophy and Daniel W. Hamilton (editors), Transformations in American Legal History: Essays in Honor of Morton J. Horwitz, Cambridge: Harvard Law School, 2009, p. 51).

${ }^{37}$ Ver, e.g., The Records of the Virginia Company of London, Susan Myra Kingsbury (editor), Washington, D.C.: U.S. Government Printing Office, 1906-1935, v. 2, p. 469 (Court Record, Oct. 1623).

38 Em William Strachey, For the colony in Virginea Britannia. Lavves diuine, morall and martiall, \&c, London: Printed for W. Burre, 1612, não havia referências à foral ou patente.

39 BILDER, Mary Sarah. Colonial Constitutionalism and Constitutional Law. In: BROPHY, Alfred L.; HAMILTON, Daniel W. (Editors) Transformations in American Legal History: Essays in Honor of Morton J. Horwitz. Cambridge: Harvard Law School, 2009, p. 33

40 WINTHROP, John. Discourse on Arbitrary Government. In: Massachusetts Historical Society. Winthrop Papers. Volume 4. Boston: John Wilson and Son, 1929-1947, p. 468.

${ }^{41}$ WINTHROP, John. Discourse on Arbitrary Government. In: Massachusetts Historical Society. Winthrop Papers. Volume 4. Boston: John Wilson and Son, 1929-1947, p. 471. Winthrop notavelmente comentou que ele "pode demonstrar uma regra clara da própria patente" (ibid., p. 472).

42 WINTHROP, John. Discourse on Arbitrary Government. In: Massachusetts Historical Society. Winthrop Papers. Volume 4. Boston: John Wilson and Son, 1929-1947, p. 483.

${ }^{43}$ Edward Winslow, The Danger of Tolerating Levellers in a Civil State, London: Printed by Rich, 1649, p. 78 (uma publicação posterior de Hypocrisy Unmasked).

${ }^{44}$ BARBADOS. [Acts and statutes] of the island of Barbados made and enacted since the reducement of the same, unto the authority of the Common-wealth of England and set forth the seventh day of September, in the year of our Lord God 1652, by the Honourable governour of the said island, the worshipfull the council, and gentlemen of the assembly; together with charter of the said island, or articles made on the surrender, and rendition of the same; published for the publick good. London: Printed by Will Bentley, 1654. O foral da Companhia das Indias Orientais foi publicado em 1661, e aquele das Ilhas Bahamas em 1670.

45 Virginia and Maryland: or, The Lord Baltamore's printed case, uncased and answered shewing the illegality of his patent and usurpation of royal jurisdiction and dominion there (1655). O próprio panfleto de Baltimore também utilizou a palavra "patente". Cecil Calvert Baltimore, The Lord Baltemores Case Concerning the Province of Maryland, adjoyning to Virginia in America. London: [s.n.], printed in the yeare, 1653 (Mary Sarah Bilder, Colonial Constitutionalism and Constitutional Law, In Alfred L. Brophy and Daniel W. Hamilton (editors), Transformations in American Legal History: Essays in Honor of Morton J. Horwitz, Cambridge: Harvard Law School, 2009, p. 52). 
${ }^{46}$ BILDER, Mary Sarah. Colonial Constitutionalism and Constitutional Law. In: BROPHY, Alfred L.; HAMILTON, Daniel W. (Editors). Transformations in American Legal History: Essays in Honor of Morton J. Horwitz. Cambridge: Harvard Law School, 2009, p. 34.

47 PATTERSON, Catherine F. Urban Patronage in Early Modern England: Corporate Boroughs, the Landed Elite, and the Crown, 1580-1640. Stanford, Calif.: Stanford University Press, 1999, p. 165. Sobre a antiga constituição de Massachusetts colonial, ver Hart and Ross, The Ancient Constitution in the Old World and the New, in: BREMER, Francis J.; BOTELHO, Lynn A. (editors), The World of John Winthrop: Essays on England and New England 1588-1649, Boston: Massachusetts Historical Society, 2005 (Mary Sarah Bilder, Colonial Constitutionalism and Constitutional Law, In: Alfred L. Brophy and Daniel W. Hamilton (editors), Transformations in American Legal History: Essays in Honor of Morton J. Horwitz, Cambridge: Harvard Law School, 2009, p. 52).

48 Sobre a Carta Magna nas colônias, ver A. E. Dick Howard, The Road from Runnymede: Magna Carta and Constitutionalism in America, Charlottesville: University of Virginia Press, 1968

${ }^{49}$ Lois G. Schwoerer, The Ingenious Mr. Henry Care: Restoration Publicist, Baltimore, Md.: Johns Hopkins University Press, 2001, p. 232 (a descrever a recepção estadunidense e inglesa). Como observa Schwoerer, o documento forneceu "documentos constitucionais, precedentes ingleses e linguagem convincente sobre os direitos e liberdades dos ingleses" e serviu como um "manual que tornou a Carta Magna e outros documentos prontamente acessíveis". Ela salienta que Penn "silenciosamente plagiou uma parte considerável" em The Excellent Priviledge of Liberty \& Property (1687) (p. 233). Um dos primeiros defensores da grafia "ch" parece ter sido, não surpreendentemente, o inglês Edward Coke (Mary Sarah Bilder, Colonial Constitutionalism and Constitutional Law, In: Alfred L. Brophy and Daniel W. Hamilton (editors), Transformations in American Legal History: Essays in Honor of Morton J. Horwitz, Cambridge: Harvard Law School, 2009, p. 52).

${ }^{50}$ BULKELEY, Gershom. The People's Right to Election: or, Alteration of Goverment in Connecticut. Philadelphia: Printed by Assignes of William Bradford, 1689, pp. 2, 15.

${ }^{51}$ BILDER, Mary Sarah. Colonial Constitutionalism and Constitutional Law. In: BROPHY, Alfred L.; HAMILTON, Daniel W. (Editors). Transformations in American Legal History: Essays in Honor of Morton J. Horwitz. Cambridge: Harvard Law School, 2009, p. 35.

52 HALLIDAY, Paul D. Dismembering the Body Politic: Partisan Politics in England's Towns, 1650-1730. Cambridge: Cambridge University Press, 1998, p. 26. Halliday escreve que aqueles "a especular sobre a natureza das corporações gostavam de dizer que a forma exata das palavras no foral não era importante para o estabelecimento da corporação ou para definir seus privilégios. Mas nas décadas após 1660, os termos do foral foram mais bem definidos." À medida que ele cita, Sir Robert Atkyns declarou, "O foral dá o único governo" (p. 40-41) (Mary Sarah Bilder, Colonial Constitutionalism and Constitutional Law, In: Alfred L. Brophy and Daniel W. Hamilton (editors), Transformations in American Legal History: Essays in Honor of Morton J. Horwitz, Cambridge: Harvard Law School, 2009, pp. 52-53).

53 Ver, e.g., CORPORATION OF LONDON. The abridgement of the charter of the city of London being every free-man's privilege / exactly translated from the original record and rendered faithfully into English according to the said record itself from the time of William the Conquerour ... to the time of our now Sovereign Lord King Charles the Second ... [s.n.], London, 1680; CORPORATION OF LONDON. The royal charter of confirmation granted by King Charles II to the city of London. Wherein are recited verbatim, all the charters to the said city, granted by His Majesties royal predecessors, kings and queens of England. / Taken out of the records, and exactly translated into English by S.G. gent.; Together with an index or alphabetical table, and a table explaining all the obsolete and difficult words in the said charter. London: Printed for Samuel Lee and Benjamin Alsop, 1680.

${ }^{54}$ BILDER, Mary Sarah. Colonial Constitutionalism and Constitutional Law. In: BROPHY, Alfred L.; HAMILTON, Daniel W. (Editors). Transformations in American Legal History: Essays in Honor of Morton J. Horwitz. Cambridge: Harvard Law School, 2009, p. 35.

55 BILDER, Mary Sarah. Colonial Constitutionalism and Constitutional Law. In: BROPHY, Alfred L.; HAMILTON, Daniel W. (Editors). Transformations in American Legal History: Essays in Honor of Morton J. Horwitz. Cambridge: Harvard Law School, 2009, p. 35.

56 WILLIAM III of England; MARY II of England. The charter granted by Their Majesties King William and Queen Mary, to the inhabitants of the province of the Massachusetts-Bay, in New-England. Boston: Samuel Kneeland and Timothy Green, 1742 (1692). O foral foi reimpresso em
1699. The charter granted by Their Majesties King William and Queen Mary, to the inhabitants of the province of the Massachusetts-Bay in New-England (1699). Para outros forais, ver Hudson Bay (1690), o City of New York (1694) e Carolina (1698) (Mary Sarah Bilder, Colonial Constitutionalism and Constitutional Law, In: Alfred L. Brophy and Daniel W. Hamilton (editors), Transformations in American Legal History: Essays in Honor of Morton J. Horwitz, Cambridge: Harvard Law School, 2009, p. 53).

57 Ver, e.g., Massachusetts, The charter granted by Their Majesties King William and Queen Mary, to the inhabitants of the province of the Massachusetts-Bay in New-England, Boston: Printed by B. Green for Benjamin Eliot, 1714-1723 (precedendo The Acts and Laws). Para outros, ver Pennsylvania, A Collection of charters and other publick acts relating to the province of Pennsylvania, viz. I. The royal charter to William Penn, Esq. II. The first frame of government, granted in England, in 1682. III. Laws agreed upon in England. IV. Certain conditions or concessions. V. The act of settlement, made at Chester, 1682. VI. The second frame of government, granted 1682. VII. The charter of the city of Philadelphia, granted October 25. 1701. VIII. The new charter of privileges to the province, granted October 28, 1701 (1740); A Defence of the legislative constitution of the province of Pennsylvania, as it now stands confirmed and established, by law and charter. With some observations on the proceedings published by sixteen members of Assembly, in a paper, entitled, The votes and proceedings of the House of Representatives: recommended to the consideration of all the free men of the province, Philadelphia: printed and sold by B. Franklin, 1740 (1728); Rhode-Island and Providence-Plantations, The charter granted by His Majesty King Charles the Second, to the colony of Rhode-Island, and ProvidencePlantations in America. Rhode-Island: Printed by James Franklin, 1730 (1719); Connecticut. \& England and Wales. Sovereign (16601685: Charles II). The charter granted by His Majesty King Charles II to the governour \& company of the English colony of Connecticut in New-England in America. New-London, Conn.: Printed and sold by Timothy Green: 1718 (Mary Sarah Bilder, Colonial Constitutionalism and Constitutional Law, In: Alfred L. Brophy and Daniel W. Hamilton (editors), Transformations in American Legal History: Essays in Honor of Morton J. Horwitz, Cambridge: Harvard Law School, 2009, p. 53).

58 DUMMER, Jeremiah. A Defence of the New-England Charters. Boston: Reprinted by S. Kneeland for S. Gerrish and D. Henchman, 1721.

59 DICKINSON, John. Speech on a Petition for a Change of Government of the Colony of Pennsylvania, May 24, 1764. In: FORD, Paul Leicester (editor). The Writings of John Dickinson. Philadelphia: Historical Society of Pennsylvania, 1895, Volume 1, p. 35.

${ }^{60}$ BILDER, Mary Sarah. Colonial Constitutionalism and Constitutional Law. In: BROPHY, Alfred L.; HAMILTON, Daniel W. (Editors). Transformations in American Legal History: Essays in Honor of Morton J. Horwitz. Cambridge: Harvard Law School, 2009, p. 35-36.

${ }^{61}$ The Laws of Maryland (1765).

${ }^{62}$ FORD, Worthington C.; HUNT, Gaillard; FITZPATRICK, John Clement; HILL, Roscoe R.; HARRIS, Kenneth E.; TILLEY, Steven D. (Editors). Journals of the Continental Congress, 1774-1789. Washington, D.C.: Government Printing Office, 1904-1937. 34 vols. Utilize-se como referências as manifestações ocorridas nas datas de 10 de outubro de 1774, 2 de junho de 1775 e 9 de junho de 1775 .

${ }^{63}$ PAINE, Thomas. Common Sense. London: Penguin, 2005, sec. 4, p. 55.

${ }^{64}$ PAINE, Thomas. Common Sense. London: Penguin, 2005, p. 43.

${ }^{65}$ BILDER, Mary Sarah. Colonial Constitutionalism and Constitutional Law. In: BROPHY, Alfred L.; HAMILTON, Daniel W. (Editors). Transformations in American Legal History: Essays in Honor of Morton J. Horwitz. Cambridge: Harvard Law School, 2009, p. 36.

${ }^{66}$ Sobre a evolução da distinção entre constituição e governo, ver Willi Paul Adams, The First American Constitutions: Republican Ideology and the Making of the State Constitutions in the Revolutionary Era, translated by Rita and Robert Kimber, Lanham, Md.: Rowman \& Littlefield, 2001 (1973), p. 19 (Mary Sarah Bilder, Colonial Constitutionalism and Constitutional Law, In: Alfred L. Brophy and Daniel W. Hamilton (editors), Transformations in American Legal History: Essays in Honor of Morton J. Horwitz, Cambridge: Harvard Law School, 2009, p. 54).

67 Ver United States of America, Documentary History of the Constitution, Washington: Department of State, 1900, Volume 3, p. 7 (May 14, 1787). Madison revisou posteriormente essa frase e ela se tornou "sistema federal de governo" (Mary Sarah Bilder, Colonial Constitutionalism and Constitutional Law, In: Alfred L. Brophy and Daniel W. Hamilton (editors), Transformations in American Legal History: Essays in Honor of Morton J. Horwitz, Cambridge: Harvard Law School, 2009, p. 54). 
68 Outras colônias escreveram novos documentos que eram pouco mais do que versões reformuladas do foral. Os habitantes de Nova Jersey, por exemplo, segundo um estudioso, "embora abertamente admitissem os absurdos e os defeitos de sua constituição, estavam contentes em manter o seu foral arcaico", que "violentou o dogma da separação dos poderes". Charles R. Erdman Jr., The New Jersey Constitution of 1776, Princeton, N.J.: Princeton University Press, 1929 p. vii. Na Convenção, Ellsworth refere-se aos Articles of Confederation como um foral (Mary Sarah Bilder, Colonial Constitutionalism and Constitutional Law, In: Alfred L. Brophy and Daniel W. Hamilton (editors), Transformations in American Legal History: Essays in Honor of Morton J. Horwitz, Cambridge: Harvard Law School, 2009, p. 54).

69 Madison to Judge Roane, Sept. 2, 1819, in: Max Farrand (editor), The Records of the Federal Convention, New Haven: Yale University Press, 1966, vol. 3, doc. 131. Ele continuou: "Mais especificamente aqueles que dividem a legislação entre os governos geral e local, e que isso poderia exigir um curso regular de prática para liquidar e estabelecer o significado de algumas delas. Mas foi antecipado, creio eu, por poucos, se algum, dos amigos da Constituição, que uma regra de interpretação seria introduzida tão ampla e flexível como a que surgiu" (Mary Sarah Bilder,
Colonial Constitutionalism and Constitutional Law, In: Alfred L. Brophy and Daniel W. Hamilton (editors), Transformations in American Legal History: Essays in Honor of Morton J. Horwitz, Cambridge: Harvard Law School, 2009, p. 54).

70 BILDER, Mary Sarah. Colonial Constitutionalism and Constitutional Law. In: BROPHY, Alfred L.; HAMILTON, Daniel W. (Editors). Transformations in American Legal History: Essays in Honor of Morton J. Horwitz. Cambridge: Harvard Law School, 2009, p. 36.

71 Ver Patrick H. Hutton, The Print Revolution of the Eighteenth Century and the Drafting of Written Constitutions. Vermont History, Barre, Volume 56, Issue 3, 1988, p. 154; Michael Warner, Letters of the Republic: Publication and the Public Sphere in Eighteenth-Century America, Cambridge, Mass.: Harvard University Press, 1990 (Mary Sarah Bilder, Colonial Constitutionalism and Constitutional Law, In: Alfred L. Brophy and Daniel W. Hamilton (editors), Transformations in American Legal History: Essays in Honor of Morton J. Horwitz, Cambridge: Harvard Law School, 2009, p. 54).

72 BILDER, Mary Sarah. Colonial Constitutionalism and Constitutional Law. In: BROPHY, Alfred L.; HAMILTON, Daniel W. (Editors). Transformations in American Legal History: Essays in Honor of Morton J. Horwitz. Cambridge: Harvard Law School, 2009, p. 36. 